\title{
DETERMINACIÓN DE ZEARALENONA POR CROMATOGRAFÍA LÍQUIDA DE ALTA RESOLUCIÓN: NORMALIZACIÓN DE UN NUEVO MÉTODO PARA RACIONES ESPECIALES PARA CERDOS
}

\author{
ZEARALENONE DETERMINATION IN HIGH PERFORMANCE \\ LIQUID CHROMATOGRAPHY: A NEW STANDARDIZATION \\ METHOD FOR COMMERCIAL SWINE RATIONS
}

\author{
Janaína Susan Cover (1), Mário Lettieri Teixeira (2), \\ Luís Flávio Oliveira Souza (1), Alexandre Meneghello Fuentefría (3) \\ (1) Centro de Ciências da Saúde, Universidade Comunitária Regional de Chapecó, Brasil. \\ (2) Curso de Medicina Veterinária, Instituto Federal Catarinense. Campus Concórdia, Brasil. \\ (3) Departamento de Análises, Universidade Federal do Rio Grande do Sul, Brasil.
}

\begin{abstract}
The aim of this work was to offer a new method of high performance liquid chromatography (HPLC) to evaluate commercial swine rations (CSR) contaminated by zearalenone (ZEA). After ZEA extraction and purification from CSR, the samples were eluted with acetonitrile, methanol and water solvent system. The results indicated that the proposed method showed to be rapid and efficient for the detection and quantification of ZEA in CSR, since its recovery was $102.62 \%$, it offered excellent precision with a coefficient of variation of 0.9992. Furthermore, it is also proposed a as a biocontrol assay for micotoxigenic fungi isolated and maintained in the laboratory. The test was performed with the killer yeast Trichosporum insectorum CBS 10422 against Fusarium sp and Aspergillus flavus, which demonstrated to be effective against the latter.
\end{abstract}

Key words: Zearalenone; HPLC; biocontrol.

Este trabajo fue recibido el 18 de Mayo de 2010 y aceptado para ser publicado el 24 de Agosto de 2010.

\section{INTRODUCTION}

Mycotoxins are secondary metabolites produced by some species of filamentous fungi, when exist biological and environmental factors favorable, being capable to produce poisonous effects in animals and humans (1).

The contamination of foods by mycotoxins can happen on the field during the development or maturation of the plants, during and after the crop, in their transport and storage, when exist climatic conditions favorable, as surplus moisture, insect's presence, and any factor that could lead to metabolic stress in the vegetables (1, 2). It is also important to emphasize that the relative humidity of the air, the content of the grains humidity, high temperature, light, and mechanical damages lead to toxins production by mycotoxigenic fungi presents in foods at the storage and stock places.

In a workshop about mycotoxins and ficotoxins accomplished in 1996 in Italy, sponsored by Food Agriculture Organization (FAO), it was mentioned that the aflatoxins, ochratoxin, T-2 toxin, deoxynivalenol, and fumonisins are the five main toxins or "the big five" (3). In the meantime, in Brazilian and South American, the main toxins are the patulin, trichothecenes and zearalenone (ZEA), inclusively in larger prevalence than "the big five" (4).

ZEA occurred practically in almost all grains, peculiarly in winter culture of indian corn contaminated by Fusarium spp. (3). ZEA is a mycotoxin with estrogenic characteristics, which are responsible by estrogenic syndrome in swine that lead to female infertility, spontaneous aborts and cancers (5). In accordance with the Food and Agriculture Organization (FAO), the ZEA concentration upon $1 \mathrm{ppm}$ are sufficient to development its toxigenic effects. However, in other countries like 
Austria, France, Italy, Russia and Uruguay the ZEA levels presented variability between 30 to $200 \mathrm{ppb}$ $(6,1)$. Nevertheless, the better method to control the contamination by mycotoxins is the inhibition of the growth of its respective fungi. The biological control methods represent a viable alternative when compared with chemical traditional methods; mainly do not leaves toxic residues on local application. Furthermore, they do not induce so easily microbiologic resistance (7). On the other hand, the unreasonable use of synthetic fungicides lead frequently injury to human healthy, and cause disturbances in the ecosystem, what is link to emerging of resistance fungi strains (8-10).

The killer factor is a toxic peptide capable to inhibit the growth of other microorganisms. They have been attributed like a new and good perspective to biocontrol of fungi's filaments, once that your action is not restricted to cell wall but include the inhibition of mitotic phases, responsible to sexual and non sexual fungi reproduction (11).

There are various and specific methods to determine ZEA when compared to another mycotoxins. The analytic results must guarantee the assurance, and the validation parameters must include specificity, selectivity, linearity, sensibility, limit detection, limit of quantification, robustness, precision and accuracy (12). In the case of ZEA, most methods applied are deficient in these prerogatives, without the correct standardization of advisable parameters (13).

The main contribution of this work was to propose a rapid and efficient HPLC method for detection and quantification of ZEA in commercial swine rations, such as to investigate the inhibition of mycotoxigenic fungi in vitro through the application of Trichosporum insectorum, a yeast discovered and described recently as a promising producer strain of antimicrobial agents (14).

\section{EXPERIMENTAL}

\section{Instrumentation, chemicals and solvents}

The ZEA standard (99\% purity) was bought from Sigma-Aldrich®, St. Louis, MO, USA. For determination of samples was used liquid chromatography Varian (Palo Alto, California, USA) with column C18 Microsorb-MV of 250 x 4.6mm x 1/4".

In the conditions of the operation it was used as mobile phase acetonitrile/water/methanol (5:75:10) with a flow of $1.0 \mathrm{~mL} / \mathrm{min}$ and with a fluorescence detector, wavelength $333 \mathrm{~nm}$ excitation and $460 \mathrm{~nm}$ emission. The retention time for ZEA varied from 1.9 to $2 \mathrm{~min}$.

\section{Analytical standardization of the method}

It was prepared a solution of reference of $100 \mathrm{ppb}$ of ZEA and starting from this, the concentrations of $50,10,5$ and $1 \mathrm{ppb}$, in methanol grade HPLC (Vetec ${ }^{\circledR}$, Rio de Janeiro, Brazil). The linearity was evaluated by Analysis of Variance (ANOVA).

Tests intra-day and inter-days were accomplished to determine the precision of the proposed analytical method. Concentrations different from ZEA's standard were prepared $(100,50,10,5$ and $1 \mathrm{ppb})$ and analyzed in triplicate in three different days.

The limit of detection (LOD) and limit of quantification (LOQ) of ZEA were certain determined using standard solutions. They were calculated as $3.3 \mathrm{\sigma} / \mathrm{a}$ and $10 \sigma / a$, respectively, where a is the coefficient of inclination obtained from calibration curve, and $\sigma$ is the standard deviation from intercept of the straight line.

The precision and accuracy were certain for recovery test through the addition of the standard (50 ppb) in reference solutions. The test was accomplished in triplicates.

The robustness of the proposed method was tested moving the $\mathrm{pH}$ of the middle of dissolution of the standard solution in \pm 0.1 units (for dissolution studies and stability) (data not showed).

\section{ZEA analysis in commercial swine rations (CSR)}

Twelve CSR samples were obtained from agricultural cooperative located in Chapecó city, Santa Catarina state, in southern Brazil. Such samples were collected during the month of March and April 2009, directly from silo shake apparatus, at one day interval between the collects, weighting $1 \mathrm{Kg}$ each one, which representing a CSR sample of 18.000 ton. These samples were named in according with the date and hour of collect.

In the laboratory, the lot samples were homogenized and reduced to bracket of $250 \mathrm{~g}$ for the quarteament technique (15). From the quarteament, it was removed analytical sub-samples in enough amounts for accomplishment the analysis that were storage in Falcon flasks.

Brackets of $0.5 \mathrm{~g}$ of the samples were homogenized in becker with a solution composed by methanol/water $(75: 25 \mathrm{v} / \mathrm{v})$ for 5 minutes and subjected to shaker for 30 minutes. After that, the samples were centrifuged at $3000 \mathrm{~g}$ for 10 minutes. The supernatant was collect and stored in flask properly identified.

The samples purification was performed adding $15 \mathrm{~mL}$ of diclorometane (HPLC grade) to $2.5 \mathrm{~mL}$ of supernatant. This stage was reply two timed with 10 $\mathrm{mL}$ of diclorometane. After, the samples obtained were homogenized in $1 \mathrm{~mL}$ of ultrapure water type I (Máster System Lab.,Gehaka ${ }^{\circledR}$, São Paulo, Brazil) and packing for HPLC analysis. 


\section{Biocontrol Assay}

Overnight grown target cells from A. flavus and Fusarium sp. isolates were suspended in distilled water to a density of approximately 106 cells/mL and spread on the assay Petri dishes containing yeast-malt (YM; yeast extract $0.3 \%$, malt extract $0.3 \%$, peptone $0.5 \%$, glucose $1 \%$, agar $2 \%, \mathrm{pH} 5.5)$. Inoculum suspensions (108 cells $/ \mathrm{ml}$ ) of $24 \mathrm{~h}$ grown cells of potential killer yeast $(\mathrm{T}$. insectorum, CBS 10422) was prepared, imprinted onto the sensitive filamentous fungi inoculum, and incubated at $250 \mathrm{C}$ for 7 days. The killer activity was considered positive if were an evident zone of inhibition around the killer strain inoculum. A narrow but clear inhibition zone was interpreted as a weak killer action (11).

\section{RESULTS AND DISCUSSION Analytical standardization}

The chromatography conditions were adjusted starting from several injections of standard solutions. The retention time was the same for all solutions, showing a minimal oscillated between 1,9 and 2 min. The proposed method show a coefficient of correlation of $0,9992(\mathrm{~F}=1,8304, \mathrm{p}<0,01)$, indicating an excellent linearity (figure 1).

The reproducibility was expressed in the tests intraday and inter-day. The values achieved for intra-day were from $0.53 \%$ to $0.982 \%$, and for the rehearsals inter-day they were from $1.17 \%$ to $1.39 \%$, what indicates a great reproducibility. The values of LOD and LOQ for this method were $0.3 \mathrm{ppb}$ (LOD) and $0.7 \mathrm{ppb}$ (LOQ). The repeatability of the retention's times, the efficiency of the analytical method employee in this work and the linearity of the studied composition was appropriate for determination of the levels of ZEA, because this standardization allowed an analysis of the presence and amount of the analyte in subject in a reduced time, reaffirming a new protocol of analysis.

The precision and accuracy were performed through the recovery assays, with standard addiction. The standard recovery percentage was calculated by formula: \% Recovery $=(\mathrm{Ct}-\mathrm{Cu}) / \mathrm{Ca} \times 100$, when $\mathrm{Ct}$ is the compound total concentration; $\mathrm{Cu}$ is the compound concentration in standard solution; and $\mathrm{Ca}$ is the rule compound concentration. The results show a recovery

\section{FIGURE 1}

Graph of the points of ZEA's calibration curve, according to the proposed method.

The used points were: $1,5,10,50$ and $100 \mathrm{ppb}$. The curve was built in the program Galaxie Chromatography Workstation version 1.9.

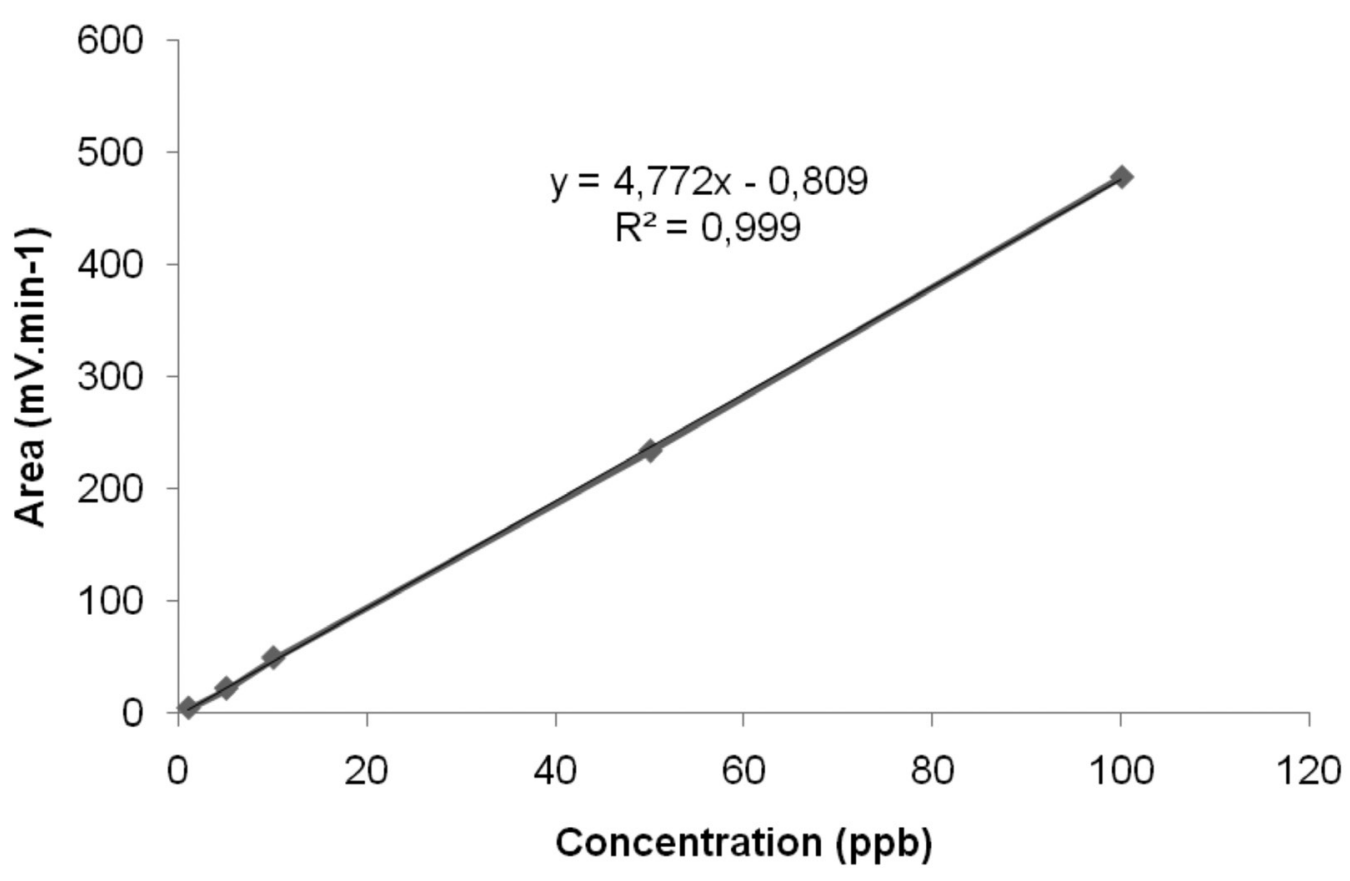


percentage of $102.62 \%(\mathrm{p}<0.05)$ to mobile phase, indicating that the method was able to reproduce repetitive results and close to the real once, that there not remarkable variation between the theory to the practice value ( $2.62 \%$ of variation).

The standard $\mathrm{pH}$ variation of ( \pm 0.1 unit) did not cause significant effect in the chromatogram area, being shown a method that can be used for samples with different $\mathrm{pH}$ strips. Furthermore, this method allow to performed the ZEA analysis in reduced time if compared with other methods what lead us emphasizing the proposition this new experimental condition of analysis as perspective of could be used at laboratorial routine as an alternative of HPLC-FL ZEA determination method $(16,17)$

\section{Evaluation of the presence of ZEA in CSR}

The samples A1 and A2 used in the standardization of the extraction technique and ZEA purification were analyzed by HPLC-FL in according to the proposed method, where it was added to the vial $50.0 \mathrm{ppb}$ and 100.0 ppb of ZEA (100 $\mu \mathrm{L})$, respectively. The presence of the toxin was observed with retention pick in approximately 5 minutes in the chromatograms (figure 2).

At figure 3, it can be observed that the toxin was not detected in all samples. Nevertheless, to the pick area expressed by some samples, the ZEA concentrations were calculated by the calibration equation, when the results showed a range of $1 \mathrm{ppb}$ to $100 \mathrm{ppb}$. On the other hand, highest levels of ZEA in CSR samples was obtained by Mallmann (18), which analyzed several samples from different parts of Brazil, at period on January 2001 to February 2004, when the contaminating average founded was $530 \mu \mathrm{g} / \mathrm{kg}$, agreeable to $15.93 \%$ of total samples analyzed.

In counterbalance, there are not studies about ZEA in CSR in western Santa Catarina State, Brazil. Sassahara et al. (19), for example, in the north Paraná State, Brazil, found ZEA contamination in STCF upon 200 $\mu \mathrm{g} / \mathrm{kg}$, which corresponded $17 \%$ from samples analyzed. Furthermore, Sakiyama et al. (20) analyzed ZEA in corn samples from Londrina, Paraná State, Brazil, between May, 1997 and March, 2003, with average for ZEA contamination samples around $448 \mu \mathrm{g} / \mathrm{kg}$. These

\section{FIGURE 2}

Chromatograms of the sample A1 with addition of $50 \mathrm{ppb}$ of ZEA (A) and of the sample A2 with addition of $100 \mathrm{ppb}$ of ZEA (B), analyzed by HPLC-FL according to the proposed method.

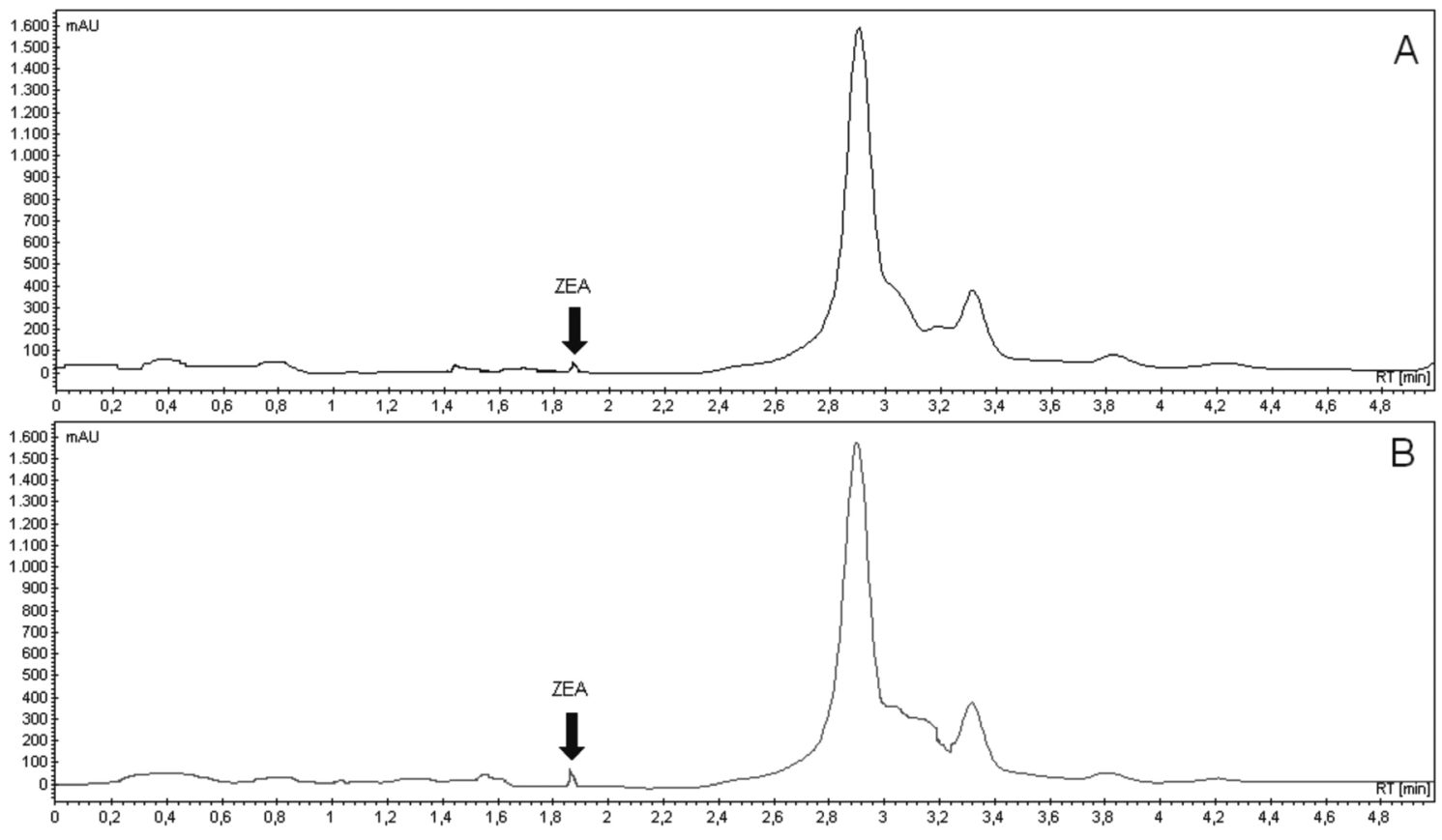


authors suggest that the ZEA levels founded is correlated to increase of rain index and weather changes on the period analyzed.

Vieira (21) after evaluated the presence of mycotoxins in wheat flour and different types of rye samples from south of Rio Grande do Sul State, Brazil, between 1995 and 1996, founding levels of OTA and ZEA around 12 and $53 \mu \mathrm{g} / \mathrm{kg}$, respectively.

Actually, almost the most of time, ZEA presented an incidence of detection much minor than aflatoxine or DON. However, when founded in high concentrations is extremely dangerous, leading to hazards and damages to public health (22).

\section{Evaluation of biocontrol assay}

Tests biocontrol performed against 10 strains of Fusarium sp. showed an inactive action of T. insectorum CBS 10422 against the isolated target. However, the killer strain showed antagonist activity against A. flavus strains, which also detected in the feed samples analyzed. The strains of A. flavus isolates demonstrated to all producers of aflatoxin in the test agar after cultivation under ultraviolet light exposure. The killer yeast strains $\mathrm{T}$. insectorum, recognized for its strong production of metabolites antagonists (14) from our results can be used for future studies of in vivo inhibition of seed contaminated with aflatoxin, but not to the strains of Fusarium sp., even that the strains showed phenotypic differences, as macromorphology and diameter of colony, ie, a low potential antagonist even for different strains of mycotoxigenic fungi.

\section{CONCLUSIONS}

In conclusion, the results suggest that the proposed method is efficient to detection and quantification of ZEA in STCF. The goal of this methodology was to offer an excellent precision, accuracy and low limit detection. Furthermore, all samples analyzed showed amounts of ZEA minor than maximum limits established by the importers of the cooperative that this study was accomplished. With the analysis of the respective found results and based on the analytical parameters, this work presents the perspective of use of this method in laboratory as an alternative for the quantification of ZEA

\section{FIGURE 3}

\section{Chromatograms of the samples analyzed by HPLC-FL according to the method proposed for quantification of ZEA. (A) Sample A. (B) Sample B.}

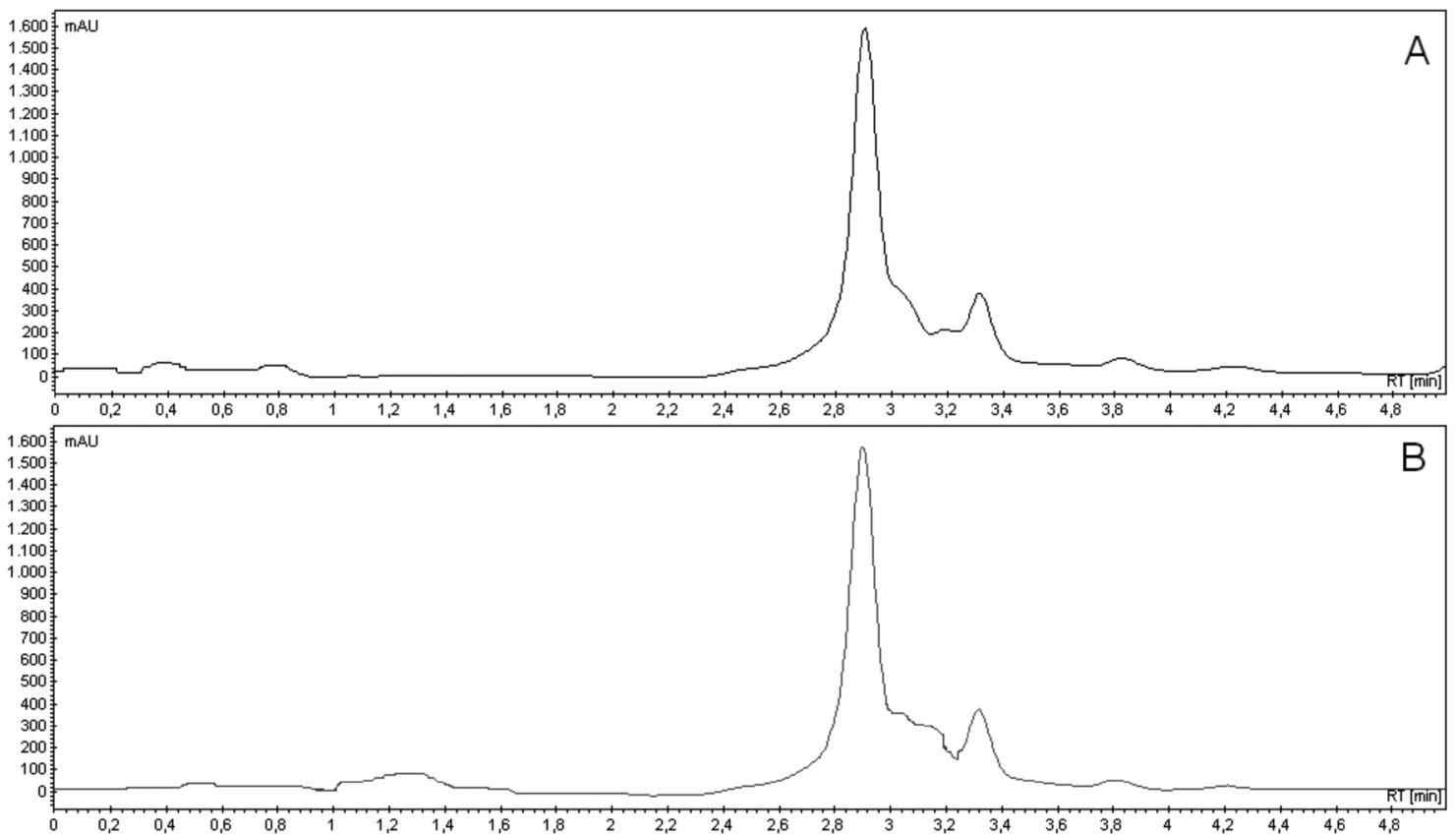


for HPLC-FL. The biocontrol assay carrying out with the killer yeast T. insectorum CBS 10422 demonstrated to be effective against A. flavus isolates in samples, but not in Fusarium sp. strains, not shown prospects for further tests of biocontrol against mycotoxigenic species produce zearalenone.

\section{RESUMEN}

El propósito de este artículo es ofrecer un nuevo método de cromatografía líquida de alta resolución (CLAR) para evaluar las raciones especiales para cerdos (REC) contaminado con zearalenona (ZEA). Después de la extracción y purificación de ZEA, las muestras se eluyeron con acetonitrilo, metanol y agua del sistema disolvente. Los resultados indican que el método propuesto demostró ser rápido y eficaz para la detección y cuantificación de ZEA en REC, ya que sus indicadores se presentan capaces de recuperación de 102,62\%, además de ofrece una excelente precisión, con un coeficiente de variación de 0,9992 . Por otra parte, también se propone una prueba de control biológico de hongos micotoxigenic aislados y mantenidos en el laboratorio. La prueba se realizó con la levadura killer Trichosporum insectorum CBS10422 contra Fusarium sp y Aspergillus flavus, mostrando eficaces sólo contra Aspergillus.

Palabras clave: Zearalenona; CLAR; control biológico.

Correspondent to the author:

Alexandre Meneghello Fuentefria

Departamento de Análises,

Universidade Federal do Rio Grande do Sul,

UFRGS

Avenida Ipiranga, 2752. Sala 510. Santa Cecília

90610-000 - Porto Alegre, RS - Brasil

e-mail: alexmf77@gmail.com

\section{REFERENCES}

1. Sabino M. Micotoxinas em alimentos. In: Oga, S.; Camargo, M. M. de A.; Batistuzzo, J. A. de O. Fundamentos de toxicologia, 3a. edição. São Paulo: Atheneu, 2008.

2. Bennett JW, Klich M. Mycotoxins, Clin Microb Rev 2003; 16: 497-516.

3. Foroud NA, Eudes F. Trichothecenes in cereal grains. Int J Mol Sci 2009; 10: 147-73.

4. Fink-Gremmels J. Mycotoxins in cattle feeds and carry-over to dairy milk: A review, Food Addit Cont 2008; 25: 172 - 80.

5. Dilkin, P. Micotoxicose suína: aspectos preventivos, clínicos e patológicos, Biológico 2002; 64: 187-91.

6. Rodriguez-Amaya DB, Sabino M. Mycotoxin re- search in Brazil: the last decade in review. Braz $\mathbf{J}$ Microbiol 2002; 33: 1-11.

7. Kabak B, Dobson AD. Biological strategies to counteract the effects of mycotoxins. J Food Prot 2009; 72: 2006-16.

8. Janisiewicz WJ, Peterson DL, Bors R. Control of storage decay of apples with Sporobolomyces roseus. Plant Dis. 1994; 78: 466-70.

9. Arras G, De Cicco V, Arru,S, Lima G Biocontrol by yeasts of blue mould of citrus fruits and the mode of action of an isolate of Pichia guilliermondii. J Hort Sc Biotech. 2008; 73: 413-18.

10. Sugar D, Spotts RA Control of postharvest decay in pear by four laboratory-grown yeasts and two registered biocontrol products. Plant Dis 1999; 83: 155-8.

11. Fuentefria AM, Suh SO, Landell MF, Faganello J, Schrank A, Vainstein MH, Blackwell M, Valente P. Trichosporon insectorum sp. nov., a new anamorphic basidiomycetous killer yeast. Mycol Res. 2007; 112: 93-9.

12. Brito N, Júnior $\mathrm{O}$, Polese L. Validação de métodos analíticos: estratégia e discussão. R Ecotoxicol Meio Ambiente 2003; 13: 129-46.

13. Nováková L, Vlcková H. A review of current trends and advances in modern bio-analytical methods: Chromatography and sample preparation, Anal Chim Acta 2009; 656: 8 - 35 .

14. Fuentefria AM, Faganello J, Pazzini F, Schrank A, Valente P, Vainstein M. Typing and patterns of cellular morphological alterations in Cryptococcus neoformans and Cryptococcus gattii isolates exposed to a panel of killer yeasts. Med Mycol 2008; 45: 503-12.

15. BRASIL, Resolução RE $n^{\circ} 899$, de 29 de maio de 2003. Guia para a Validação de Métodos Analíticos e Bioanalíticos. Diário Oficial da União, Brasília, 02 de Junho de 2003.

16. Gromadzka K, Waśkiewicz A, Goliński P, Swietlik J. Occurrence of estrogenic mycotoxin - Zearalenone in aqueous environmental samples with various NOM content Water Res. 2009; 43: 1051-9.

17. Thieu NQ, Ogle B, Pettersson H. Screening of Aflatoxins and Zearalenone in feedstuffs and complete feeds for pigs in Southern Vietnam. Trop Anim Health Prod 2008; 40: 77-83.

18. Mallmann P. Determinação dos índices de contaminação por aflatoxina e zearalenona em rações para consumo animal no Brasil no período de janeiro de 2001 a fevereiro de 2004. XVI congresso estadual da medicina veterinária e V congresso de medicina veterinária do conesul, Santa Maria, Brasil. 2004. 
19. Sassahara M, Yanaka E, Netto DP. Ocorrência de aflatoxina e zearalenona em alimentos destinados ao gado leiteiro na Região Norte do Estado do Paraná. Semina 2003; 24: 63-72.

20. Sakiyama BL, Ribeiro AB, Machinski PA, Machinski JM. Aflatoxins, ochratoxin A and zearalenone in maize-based food products. Braz J Microbiol 2005; $36,289-94$.
21. Vieira A P. Ocorrência de micotoxinas e características físico-química de farinhas comercializadas na zona sul do Rio Grande do Sul. Rev Soc Bras Cienc Tecnol Alim 1999; 19: 221-5.

22. Richard JL. Some major mycotoxins and their mycotoxicoses. An overview. Int J Food Microbiol 2007; 119: 3-10. 